\title{
Investigating the Match and Mismatch between Students' Learning Styles and Teacher's Teaching Styles in a Saudi School: A Case Study
}

Alaa Q. Alhourani

Assistant Professor of Linguistics, College of Arts and Science, Department of English, Jouf University, Saudi Arabia

Corresponding Author: Alaa Q. Alhourani, E-mail: aqalhourani@ju.edu.sa

\section{ARTICLE INFORMATION}

Received: December 15, 2020

Accepted: February 10, 2021

Volume: 3

Issue: 2

DOI: 10.32996/jweep.2021.3.2.2

\section{KEYWORDS}

Learning Styles, Teacher's Teaching Styles, Saudi School, Saudi Arabia

\section{ABSTRACT}

This study examines if there is a match or mismatch between students' learning styles and the teacher's teaching styles in a classroom at Khalid Bin Alwlid School, Tabarjal, Saudi Arabia. The main objectives of this study are to determine dominant learning styles of the whole secondary grade students and the teacher's teaching style. This study was carried out as a case study, and the data were analyzed qualitatively and quantitatively. Participants of this study were a class of 15 students and their English language teacher to the first secondary stage. The instruments used for collecting data were Reid's Perceptual Learning Style Preference Questionnaire (1995), Teachers Teaching Style Preferences Questionnaire (Peacock 2001), and semi-structured interview. The findings of this study indicated that the majority of the students had multiple learning styles with at least auditory and group as their major learning style preferences, followed by kinesthetic, tactile, and visual as their minor learning style preferences. They showed negative preference towards individual style. The major learning style preferences of the English language teacher were visual and individual, followed by tactile and kinesthetic as his minor style preferences, while his negligible teaching style preferences were auditory and group. There was a mismatch between the teacher's teaching style and the students' learning style at Khalid Bin Alwlid School, Tabarjal, Saudi Arabia

\section{Introduction}

During the last couple of decades, the world has been concerned with cultural, social, political and technological changes. In order to keep up with those changes, people have had to meet the needs created by all these changes. Ahmadi (2017) mentioned that language learning is one of the most important needs, and it has become an essential component in people's lives. People all over the world are trying to learn a second language, even a third language in order to cope with these changes. Al-Khatib (2000) cited in Qasim (2007, p. 49) states that "teaching English and other European language as a foreign or second language in the Arab world can be traced back to the 1920s, when different parts of the region came under the British and French authorizations". Therefore, the increase in the use of English as a lingua franca, made most Arab governments to give their attention to introduce the teaching of English into the school curriculum.

Learners' learning style is one of the most significant factors in influencing how learners learn a second language as Goklap (2013) stated that learning style gives the most powerful effect to motivate, and assist students in school. The accomplishment, however, is very much reliant not only on learner's learning style, but also on teacher's teaching style. On the other hand, there has always been a distinction between learners' learning styles and teacher's teaching style. Each person is unique in the way he prefers to receive information. The ways in which an individual acquires, retains and retrieves information are collectively termed the individual learning styles. Therefore, every learner is unique. Every teacher is unique. And every teacher-learner relationship is unique.

Due to the immature development of in-depth research of learning styles in Saudi Arabia there has always been lack of information on the kind of learning styles adopted by the Saudi students, particularly in learning a foreign language because the

K C AL-KINDI CENTER $R$ FOR RESEARCH AND R DEVELOPMENT Your gateway to world-class research

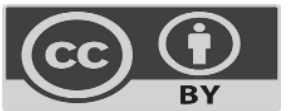

Published by Al-Kindi Center for Research and Development. Copyright (c) the author(s). This open access article is distributed under a Creative Commons Attribution (CC-BY) 4.0 license 
teachers in Saudi Arabia use the traditional methods to teach them such as a teacher-centred, book-centred and grammar translating method (GTM). So, they would teach by using the way they learned. Robinson \& Dearmon (2013) stated that teaching style and teacher's learning style are closely interrelated, whereas teachers frequently teach with the same methods by which they learn most effectively. Hence, the efforts of the educational system to identify learners' styles and therefore to employ this information in developing their knowledge among our students, and consequently, affecting their academic achievement.

Researchers in the teaching and learning language have been trying to find out teaching methods, classroom techniques, and instructional materials that will promote better language learning. However, in spite of all these efforts there has been a growing concern that learners have not progressed as much as it was anticipated. Because there are considerable individual differences in language learning such as gender, age, social status, motivation, attitude, aptitude, and culture; what works for one learner might not work for another as Fleming (2002) said that learning style refers to all components that might affect a person's ability to learn. Therefore, none of the methods and techniques have proven that they can work all the time, in all classes, with all students. As a result, it might be appropriate to comply with Grenfell and Harris' (1999) statement that "Methodology alone can never be a solution to language learning. Rather it is an aid and suggestion" (p. 10).

Having reached this conclusion some other people in the teaching and learning language changed the focus from the language teaching methodology to the language learner and the variables that affect language learning. This shift of the focal point has led to an increase in the number of studies carried out regarding learner characteristics and foreign or second language learning. However, they have not been investigated on their own. Some other variables affect them such as gender, achievement, motivation, career orientation, national origin, and aptitude. The ultimate goal of this study is to have the EFL teachers become aware of different learning styles among their students, so they can consciously adjust, adapt or modify their teaching approaches to match students' learning preferences in order to increase learning.

Past research clearly demonstrates that learning styles influence how students learn, how teachers teach and how teachers and students interact in the classroom (Awla 2014). Teachers who fail to recognize the unique characteristics of their students' learning preferences may also fail to provide a solid foundation for educational success. In order to teach successfully to a wide range of learners, teachers must come to recognize and promote the learning/ cognitive styles of their students (Awla, 2014; Bradshaw, 2007).

In the other hand, the more teachers know about their own teaching and learning styles, the easier it will be for them to see specific ways their styles can be amplified or modified. Once teachers gain an appreciation of the variety of learning styles, they can respect learning style differences and adapt their teaching styles for different situations. They may also be alert to situations in which students' learning styles limit their success in academic areas.

However, Research studies have shown that matching teaching styles to learning styles can significantly enhance academic achievement, students' attitude and student's behavior of the elementary and secondary school levels (Miller, $2000 \&$ Zhenhui, 2001).

\subsection{Statement of the problem}

The main problem among Saudi students is their lack of English language proficiency. AL-Wajwaj (2010) stated that despite of the fact that English has taught in Arab countries as a foreign language, the lack of its proficiency is still apparent among most Arab graduates. One of the main reasons for such deficiency could be due to the unawareness of the teaching and learning styles among Saudi teachers as well as students. In addition, Elttayef \& Hussein (2017) stated that the unawareness of the learning styles might contribute to the low level of most Arab students in acquiring a good English language ability.

Many researchers (Reid 1995; Moussa 2014 \& Peacock 2001) have emphasized the crucial and important role of learning styles in language learning. For example; Reid (1995) supports this idea by stating that developing an understanding of learning environments and styles "will enable students to take control of their learning and to maximize their potential for learning" (xiv).

In the Saudi high school, students receive instruction by the traditional method. The lack of English language proficiency arises when teachers were not aware of the student's learning styles and this problem will affect their achievements negatively. Teachers may discover that some of the students perform well and some of them have a problem to acquire the language. Some of the teachers may ask their students to do as much work as possible so that the students will benefit from them, but they do not realize that each student has different preferences in learning styles. Perhaps only some of the students can learn something by doing certain activities in class but the others think it was boring and apathetic to learn. Reid (1995) mentioned that all students have their own learning styles and learning strengths and weaknesses. Moreover, Brown (2007) supports the idea by stating that people learn in many different ways. For example, some people learn primarily with their eyes (visual 
learners) or with their ears (auditory learners); some people prefer to learn by experience or by hands on tasks (kinesthetic or tactile learners); some people learn better when they work alone while others prefer to learn in groups.

In addition to that, whenever learning achievement is concerned, the match between the teachers' teaching styles and learners' learning styles is essential. Kharb et al. (2013) mentioned that students could achieve more when they receive instruction in a manner that matches their learning styles. Thus, it is undeniable that one of the causes of the Saudi students' lack of proficiency due to the students' learning styles that ignored as a significant component in the learning process, and teachers are not aware that their teaching style preferences may differ from their students learning styles. In other words, there seems to be a mismatch between the learning and teaching styles among the secondary grade students and teacher at Khalid Bin Al-Walid School in Saudi Arabia. In relation to this, Reid's (1995) study found that a mismatch between teaching and learning styles causes learning failure, frustration, and demotivation.

Clearly, most of the teachers in Saudi Arabia seldom give attention to the problem of the learning and teaching styles among them and their learners. Saudi teachers may not realize that knowing students learning styles would make the learning and teaching process easier, which is due to the lack of research in this regard. Therefore, the researcher of the current study will fill this gap by examining the match and mismatch between the learning styles of students and the teaching styles of the teacher in real life classroom teaching in a Saudi school.

\subsection{Objectives of the study}

The current study examines if there is a match or mismatch between the students' learning styles and the teacher's teaching styles in a classroom at Khalid Bin Al-Walid School, Jouf, Saudi Arabia. The main objectives of this study are to determine dominant learning styles of the whole secondary grade students and the teacher's teaching style.

\subsection{Questions of the study}

Based on the research objectives, this study aims to answer the following questions:

1) What are the major perceptual and the sociological learning styles of students in learning English of the first secondary grade at Khalid Bin Al-Walid School?

2) What are the perceptual and sociological teaching style preferences of the teacher and his reaction towards students' learning styles?

3) Is there a match/ mismatch between the students' learning style preferences and their teachers' teaching style preference?

\subsection{Significance of the study}

Many people seem to ignore individual styles in the learning process. It is important for us to realize that people learn in many different ways (Reid 1995). Many researchers (Elttayef \& Hussein, 2017; Goklap, 2013) have done the research on learning and teaching styles. They suggested that follow up research should be conducted in order to create a meaningful learning and teaching environment for both teachers and students.

This study might be one of few studies to investigate Saudi students' learning styles in the learning of English as a foreign language (EFL). In fact, the results of this study are important in a way that would identify the strengths and weaknesses of the foreign language learning process among Saudi students and research exploring this area is needed to help EFL teachers understand differences in preferred teaching styles and learning styles of Saudi students. According to Dasari (2006) and Rogers (2009) further research should be carried out to investigate the area of learning style and teaching style. Thus, it is hoped that the findings of this study would contribute to the field of language learning and teaching studies among Saudi students and teachers.

It is significant to find out if there is a match or mismatch between teaching and learning style in the Saudi secondary school classroom in order to support students to develop their learning style to overcome the problems that they might encounter when their learning style preferences are incongruent with their teachers' teaching styles. This is because this research may raise students' awareness in Saudi Arabia regarding their learning styles and make them not only more prepared for learning but also more analytic about their learning styles. Reid (1995) states that developing an understanding of learning environments and styles "will enable students to take control of their learning and to maximize their potential for learning" ( $p$. xiv).

Furthermore, students must be aware of their learning styles, which are used to enable them to be successful in their studies, and to achieve the ultimate accomplishments in their academic demands. In addition, the current research exposes students to their learning styles so that they can harness their learning styles or find out, which learning styles suit them with the teacher's teaching styles. Last but not least, the current study may benefit scholars, educators, teachers as well as students. 


\section{2. literature review}

\subsection{Learning and teaching styles}

Many scholars have studied the learning and teaching styles in different contexts depending on the nature of their studies. Sarasin (1998:3) defines learning styles as "the preference or predisposition of an individual to perceive and process information in a particular way or combination of ways". While Grasha (2002) defined teaching styles as "Enduring preferences that faculty display in the attitudes and behaviors they exhibit in their teaching and learning interactions with students... [these are] reflected in how faculty present themselves to students, convey information, interact with learners, manage tasks, supervise work in process, and socialize learners to the field" (p. 140).

Learning style is based on research that reveals that as the result of heredity, surroundings, and current environmental hassle that people from different background process information differently. As for Reid (1985), she divides learning styles into six types. The first one is visual major learning style preference. This type of learner remembers and understands information and instructions better if they read them. The second is auditory major learning style preference where the learners will remember information by reading aloud or moving their lips as they read, especially when they are learning new material. The third is kinaesthetic major learning style preference where the learners will remember information well when they actively participate in activities, field trips, and role-playing in the classroom. Next is tactile major learning style preference where the learners work on experiments in a laboratory, handling and building models, and touching and working with materials provides them with the most successful learning situation. All these are called perceptual learning styles. The fifth is group major learning style preference which where the learners value group interaction and class work with other students and they remember information better when they work with two or more classmates. The last learning style preference is individual. Learners think well when they study alone and they remember information they learn by themselves. The fifth and last are called sociological learning styles.

\subsection{Previous studies}

For many years, researchers have investigated the relationship between how individuals learn and how teachers' influence that learning process. Among the authors that have done research on this topic are as follows.

Wong Sing Ying (2004) studied learning style preference, which focused more on gender, proficiency, similarities and differences with teaching style among the UTM students found that male and female students share the same preferences of learning styles, whereas high and low proficiency students exhibited different learning styles in language learning. On the other hand, the study also found that the teaching styles of language instructor varied and were influenced by instructional program but the teaching styles of language instructors were more similar to the learning styles employed by high proficiency students. Sing focused on different races, gender, and proficiency as the main variables in their study, while in the current study, the participants are all males and from the same race and culture.

In addition, Rosniah (2006) conducted a study on sixteen first-year Bachelor of Arts in English language studies students from UKM, Malaysia, who received fewer satisfactory scores in the English Placement Test to investigate whether low proficient students could adapt to other learning styles. She used a perceptual learning style preferences questionnaire to find out the preferred learning styles of the students, projection technique, journal writing and semi structured interview. The results showed that the majority of the students had multiple learning styles with at least kinesthetic or tactile as their major learning style preference and they had difficulties adapting to other learning styles. This study is compatible to the current study respondents in both of them studied English as a foreign Language and employed the same instrument for collecting data.

Finally, Peacock's (2001) study investigated Reid's (1987) hypothesis that a mismatch between teaching and learning styles causes learning failure, frustration, and demotivation. Data collected through Reid's questionnaire, interviews, and tests using 206 EFL students and 46 EFL teachers at a Hong Kong university found that learners favoured kinaesthetic and auditory and disfavoured both individual and group styles, while teachers favoured kinaesthetic, group and auditory styles and disfavoured tactile and individual styles. In addition, his study found a mismatch regarding group and auditory styles among students' learning styles and instructors' teaching styles; interviews revealed that $72 \%$ of the students were frustrated by a mismatch between teaching and learning styles; $76 \%$ said it affected their learning, often seriously; and $81 \%$ of the teachers agreed with Reid's hypothesis.

\section{Methodology}

\subsection{Research design}

The study was carried out as a case study. According to Creswell (2015), he stated that the basic idea of a case study is that one case or small number of cases will be studied in detail using whatever methods that seem appropriate to understand the case in depth. A case study research employs a number of research instruments to secure data, such as questionnaire, interview. In this 
research, mixed methods were applied by using quantitative and qualitative methods. Two types of questionnaires were used as quantitative data and semi structured interviews were used as qualitative data.

\subsection{Subject and setting}

The subjects of the study were purposely chosen. The subjects of this study were one class-first secondary grade students of public high school in Saudi Arabia, Tabarjal, which comprised 15 students in addition to one EFL teacher teaching at the first secondary grade at Khalid Bin Al-Walid School in Saudi Arabia. All the fifteen students were males, and their age ranged between 16-18 years old. The English teacher in this case study was Mr. Mohammad. He is male and 32 years old. He has been teaching English in this school since 2015. The setting in which this study happens, which is the Saudi High school, Khalid Bin AlWalid, located in Jouf province, Tabarjal.

\subsection{Instruments}

\subsubsection{Questionnaires}

A questionnaire is a research instrument consisting of a series of questions and other prompts for gathering information from respondents. Although they are often designed for statistical analysis of the responses, this is not always the case. In this study, the researcher used questionnaire because by using this method he can collect the data, he wanted to answer the questions of the study and get the results which should serve the objective of that study.

To elicit the data for this study the researcher used the learning style questionnaire adopted from (Reid, 1995) and teaching styles questionnaire adopted from (peacock, 2001). Many scholars (Oxford, Ehrman \& Lavine, 1991) have emphasized their researches by using those questionnaires. The researcher believes that the questionnaire will be a suitable tool to collect the data because it is a research instrument consisting of series of questions prompts for gathering information from the respondents.

\subsubsection{Semi-Structured Interviews}

In addition to the two questionnaires, the researcher interviewed selected students and their teacher. The interview will support the questionnaire' results and help the researcher to get more insights into the students' responses in a face-to-face meeting. Seidman (2006:7) asserts that "interviewing is a powerful way to gain insights into educational issues through understanding the experience of the individuals whose lives constitute education. As a method of inquiry, interviewing is most consistent with people's ability to make meaning through language".

A set of interview questions were constructed based on the information on the questionnaire. Interviews were conducted with selected students and their teacher. The audio-taped utterances of the interviews were transcribed based on Gail Jefferson's system transcription (1979) to find out information related to learning and teaching styles and whether there is any match/mismatch between the learning styles and teacher's teaching styles. The interviews with the selected students and their teacher were conducted after they filled the questionnaires.

\section{Data Analysis}

The data analyzed based on perceptual learning style questionnaire, teacher teaching style questionnaire, and the semistructured interviews.

\subsection{Perceptual Learning Style Preference Questionnaire.}

The questionnaire contains of 30 statements cover Reid's six learning style preferences which are visual, auditory, tactile, kinaesthetic, individual, and group. Students were asked to respond to each statement of the questionnaire as it applied to their study of English on a five points scale (strongly agree/ agree/ undecided/ disagree/ strongly disagree).

Reid (1995) classified the styles as major, minor, or negligible. Major is a preferred learning style, minor is one in which learners can still function well, and negligible means learners may have difficulty to learn. The researcher then analysed the data based on Reid's scale for learning styles categories (See Table 4.1). This was done based on Reid's calculation. When the numerical value was assigned to the corresponding learning style, the numbers added to obtain a total score and then it multiplied by 2 determining the major, minor, negligible learning style.

Table 4.1 Scale for learning style categories

\begin{tabular}{lc}
\hline Major learning style preference & $38-50$ \\
\hline Minor learning style preference & $25-37$
\end{tabular}


The student who scored total marks of 38 or above for each learning style represented his major learning style, if the student scored total marks between 25-37; it showed his/her minor learning style. While if the student scored 24 or below, it showed that the student is negligible in that style.

\subsection{Teachers Teaching Style Preferences Questionnaire}

This questionnaire is a modified version of the PLSPQ by Peacock (2001) used to identify language teaching styles. The teacher was asked about his teaching style, using the same six categories as the students' questionnaire. The English language teacher was asked to respond to each of the 12 statements as it applied to his teaching of English, and used a different 5 - point scalealways/ often/ sometimes/ rarely/ never.

The classification of teaching style also used "major", "minor", or "negligible". In addition, when the numerical value was assigned to the corresponding teaching style, the numbers added to obtain a total score and then it multiplied by 5 determining the major, minor, or negligible learning style according to the table 4.1. This questionnaire was distributed to the English teacher in order to find out teaching style information and to determine if there was a match or mismatch between teaching and learning styles.

\subsection{Semi- structured Interviews.}

Interviews with the selected students and their teacher were transcribed based on Gail Jefferson's system transcription (1979) to find out information related to learning and teaching styles, and if there was a match/ mismatch between teaching and learning styles.

The transcribed data on the interviews were then analysed according to the following steps. Firstly, the researcher read through the interview responses and categorized them into several themes which emerged. They were their preferred ways of studying, reaction toward teacher's teaching style and sociological style to give better understanding of students' learning style preferences. Secondly, the researcher analysed the interview with the teacher according to the same themes which merged from the interviews with the selected students. They were in relation to his preferred way of teaching, reaction toward students' learning style and sociological teaching style preferences. Finally, since the study is a case study, the researcher realizes the need of gathering both quantitative and qualitative data for the validity and reliability of the research. The data from the questionnaire were analysed quantitatively by using tables and figures, while the data from the interviews were analysed qualitatively.

\section{Results}

This section presents the findings of the students learning styles and teacher teaching styles at Khakid bin Alwlid school, Saudi Arabia based on the data collected from the questionnaires and the semi-structured interviews. Research question one "What are the major learning styles of students in English at the first secondary grade in Khalid Bin Alwlid School?" was to find out the learning styles of the whole class at Khalid Bin Alwlid school in Saudi Arabia. Figure 5.1 indicates the overall results of the data from the Perceptual Learning Style Questionnaire of the whole first secondary grade students in the school.

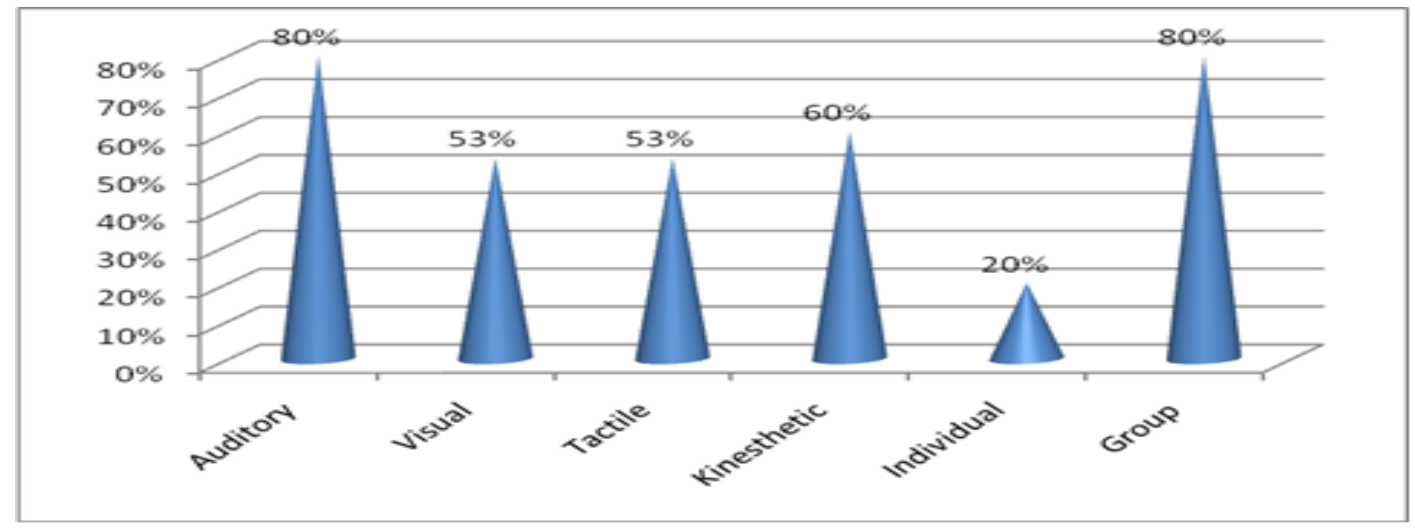

Figure 5.1 The whole group of first secondary grade Jordanian students' major preference of learning style 
Figure 4.1 indicates that the most representative and popular style was the auditory and group that means the majority of the first secondary grade students in Khalid Bin Alwlid school had multiple learning styles. The results indicate their percentage as major learning style (80\%), followed by kinesthetic style (60\%). Whereas, tactile and visual were (53\%) and only (20\%) of students prefer individual style. This can be seen from the extracts below:

$\mathrm{R}$ (researcher) S (student)

Extract 1:

R: Do you like to study in group or individual?

S: I like group

R: why?

S: to share our thoughts and ideas

R: How do you feel while you are studying in this way?

S: more comfortable to help each other

Extract 2:

R: Do you prefer your teacher to teach according to his teaching style or to your own style?

S: I don't have any problem to follow the teacher because he has experience to guide us but I will be happy if he follows my style.

R: why?

S: it's easy to understand hahahah

R: Which do you prefer; listening to the teacher's explanations or reading them?

S: listening is better

R: why?

S: I like listening more than reading because I memorize better on this way.

Research question two "What are the perceptual and sociological teaching style preferences of the teacher and his reaction towards students' learning styles?" was to find out the teaching styles of the teacher at Khalid Bin Alwlid school in Saudi Arabia. Figure 5.2 shows the overall findings of Mr. Mohammad's teaching style preference according to Teacher Teaching Style Questionnaire.

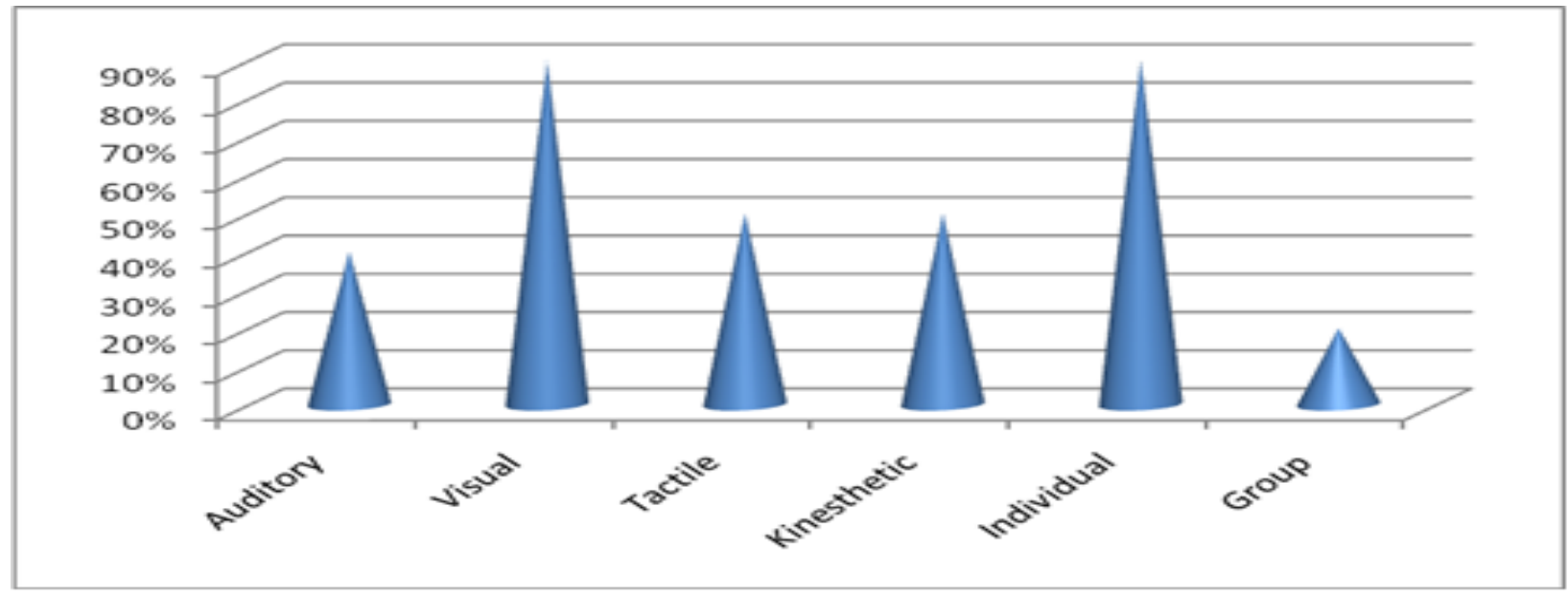

Figure 5.2 Mr. Mohammad's teaching style preferences 
Figure 5.2 shows the results of the Teacher Teaching Style Questionnaire of Mr. Mohammad's teaching style preferences where visual and working individually were the highest percentage in his teaching style with $90 \%$ followed by kinesthetic and tactile with $50 \%$ while auditory was $40 \%$ and $20 \%$ for working as group.

Table 5.1 Mr. Mohammad's teaching style scores

\begin{tabular}{|c|c|c|c|c|c|c|c|}
\hline & Score & Auditory & Visual & Tactile & Kinesthetic & Individual & Group \\
\hline Major & $38-50$ & & 45 & & & 45 & \\
\hline Minor & $25-37$ & & & 25 & 25 & & \\
\hline Negligible & $0-24$ & 20 & & & & & 10 \\
\hline
\end{tabular}

Table 5.1 indicates Mr. Mohammad's scores of his perceptual teaching style preferences. His major teaching style preferences were visual and individual style (45), while his minor styles were tactile and kinesthetic (25). His negligible teaching style preferences were auditory (20) and group (10).

By analyzing the data from the interview with Mr. Mohammad, the following themes emerged to give better understanding of Mr. Mohammad's teaching style in order to answer research question three in relation to his preferred way of teaching, reaction toward students' learning style and sociological teaching style preferences.

\subsection{Preferred way of studying}

From the interview it is clear that Mr. Mohammad preferred to teach by using the board in the class which means his style was visual in delivering the lesson. He stated that he used different ways of teaching according to student's level. Moreover, when the researcher asked him if he would prefer to use oral instruction, write on the board, or doing something in class, the teacher said that he usually writes on the board because the students were not proficient enough to understand orally and this way of teaching helps the students to be familiar with new words and their spelling. He also stated that according to his way of teaching he changed a little on his style to match with his student's levels as he indicated in his interview below.

R: How do you teach the students in the class?

T: Actually, I teach them in different ways

R: How?

T: It depends on their level, sometimes translate from English to Arabic, writing in the board and make a conversation and write the main points and ask them to write on their notebook when I finish my explanation.

R: Ok, which style do you use more conversation, writing on the board or doing something in the class?

T: Actually, I always write on the board because if I use conversation they will lose the ideas because they are not proficient enough to understand from conversation.

R: Do you teach in the same way?

T: Not exactly with a little bit of changes, it depends on their level

R: Do you use oral instruction or do you like to write on the board?

T: As I said before, I like to write on the board but on the same time I use oral instruction in certain situation

$\mathrm{R}$ : do you think is it the best way of teaching?

T: I think its help them to make students familiar with new words and the spelling of the words 


\section{2 Reactions toward learning style}

Mr. Mohammad claimed that he was not familiar enough in learning and teaching styles. When the researcher asked him whether he would prefer to teach according to his own style or the students learning style, he said that according to my style because he has not discovered his students learning style. He also admitted that he never allowed students to do things while he explained even the student wanted to underline the main idea, but he gave them time after his explanations finish to do whatever they like to do. The reason behind that Mr. Mohammad wanted his student to be concentrated and give him their attention to get benefits and information as he stated in his interview.

R: Do you know your student's learning style?

T: Honestly, I am not sure mmmmmmmmmm I don't think so because I am not familiar with learning and teaching styles

R: Do you prefer to teach in your own style or according to your student's style?

T: ........ According to my learning style because I haven't discovered their learning styles

R: Do you allow your students to do something while you explained? Like underline the main points in the lesson, or take notes.

T: While I was explaining of course no but I always give them time to write or do whatever they like to do when I finish my explanation because they have to give me their attention to get benefits and information.

\subsection{Working in a group or individually}

According to Mr. Mohammad, he stated that he preferred students to work individually because they will work hard independently to get high results, and he did not allow them to work as group and the reasons given by Mr. Mohammad as mentioned in his interview, was that if the students were given the opportunity to work in groups, they would waste their time, talking to each other out of their lesson, and some of them will be sleepy during their discussion as he indicated in his interview below.

R: How do you like your students to work; individually or as group?

T: Individually is better .... because they will waste their time if you allow them to work as group, one or two of them will work and others will be sleepy and they will change the lesson to other discussion ...... out of lesson because they are still teenagers.

R: Why do you like them to work in this way?

T: I like this way because they will work independently and working hard to get high results

Thus, Mr. Mohammad preferred to use visual style most of the time in teaching the first secondary class. It is noticeable from the researcher's interview with Mr. Mohammad that he was the predominant figure of the class as he did not allow for his students to do something while he explained. In addition, Mr. Mohammad stated that he changed a bit in his way of teaching to make students understand better. In terms of working in-group or working individually, he preferred students to work alone clarifying that if the students were given the opportunity to work in groups, they would waste their time, talking to each other out of their lesson, and some of them will be sleepy during their discussion.

Research question three 'Is there a match/ mismatch between the students' learning style preferences and their teachers' teaching style preference?' to determine if there was a match or mismatch between the learning styles of the students and the teaching styles of the English teacher of first secondary grade at Khalid Bin Alwlid School, Saudi Arabia.

Accordingly, there was a mismatch between the teacher's teaching style and the students' learning styles, where all the students preferred working in groups while their teacher preferred students to work individually. Moreover, all the students preferred to do something in the class (kinesthetic) as their major and minor learning style while their teacher did not allow for them to do something while he explained the lesson. In terms of the students' reaction toward the teacher's teaching style, half of them had no problem following their teacher's teaching style while the others preferred some changes in their teacher's teaching style. The teacher preferred to follow his style because he was not familiar enough with teaching and learning styles. Finally, there was a mismatch between the teacher's teaching style and the students' learning style at Khalid bin Alwlid School, Tabarjal, Saudi Arabia. 


\section{Conclusion}

The findings of this study indicated that the majority of the first secondary grade students at Khalid bin Alwlid School in Saudi Arabia had multiple learning styles with at least auditory and group as their major learning style preferences. While the English teacher, Mr. Mohammad's major teaching style preferences are visual and individual. Finally, based on all of these findings and analysis of the findings, there was a mismatch between the teacher's preferred teaching style and the four focal students' preferred learning style at Khalid bin Alwlid School, Tabarjal, Saudi Arabia.

The researcher stressed on the significance of matching teaching and learning styles in order to develop the proficiency of teaching and learning. Moreover, the classification of students' learning styles and the relationship with teachers' teaching styles has crucial implications for curricula and academic achievement. Teachers have to accommodate various learning styles of the students to match teaching and learning styles in the classroom.

Also, the researcher recommends that other studies in this area should be conducted, as the area is very broad and the research can be taken from different perspectives, with a larger sample over a longer period of time in order to achieve more generalization of the findings. Further studies should be examined to determine if teaching experience, or level of education influence teachers' teaching style preferences.

Finally, it is noticeable from the results of this research that each student has his unique learning styles, the result also suggested that it is crucial to determine students' and teachers' learning styles as main factors influence students' achievement. Moreover, teachers have to be aware of their students' diversity and creative in enhancing the teaching learning processes according to the students' learning style by combining various methods, activities and approaches to achieve the goals of teaching and learning process.

\section{References}

[1] Ahmadi, M. R. (2017). The impact of motivation on reading comprehension. International Journal of Research in English Education, 2(1), 1-7.

[2] Al-wajwaj, M. 2010. Attitudes and motivation of EFL learners: a case study at the Great Jamahiriyah School, Kuala Lumpur. [Unpublished MA], Malaysia.

[3] Awla, H. A. (2014). Learning styles and their relation to teaching styles. International Journal of Language and Linguistics, 2(3), 241-245.

[4] Bradshaw, M. J. (2007). Effective learning: What teachers need to know. Innovative teaching strategies in nursing and related health professions, 3-18.

[5] Brown, H. (1994). Principles of language learning and teaching. 3rd Edition. Englewood Cliffs, NJ.: Prentice Hall Regents.

[6] Brown, H. D. (2007). Principle of language learning and teaching. Pearson Education, Inc.

[7] Creswell, J. W. (2015). Educational research: Planning conducting, and evaluating quantitative and qualitative research .[Kindle edition] Pearson Education.

[8] Dasari, P. (2006). The influence of matching teaching and learning styles on the achievement in science of grade six learners [Doctoral dissertation] University of South Africa..

[9] Elttayef, A. I., \& Hussein, N. O. (2017). Arab Learners' Problems in Learning English Language: A Teacher Perspective. Journal of Literature, Languages and Linguistics, 40, 1-6.

[10] Fleming, N. D. (2002). Teaching and learning styles: VARK strategies. Published by the author, Christchurch, New Zealand, $5^{\text {th }}$ edition.

[11] Gokalp, M. (2013). The effect of students' learning styles to their academic success. Creative Education, 4(10), 627.

[12] Grasha, A. 2002. The dynamics of one-on-one teaching [Electronic version]. College Teaching, 50(4), 139-146.

[13] Grenfell, M., Harris, V. (1999). Modern languages and learning strategies: In theory and practice. Routledge, London. In: Grifths, C. (Ed.), Lessons from Good Language Learners. Cambridge University Press, Cambridge.

[14] Jefferson, G. (1979). A technique for inviting laughter and its subsequent acceptance. In G. Pasathas (ed), Everyday Ethno methodology. New York: Irvington, 79-96.

[15] Jester, C., \& Miller, S. (2000). Introduction to the DVC learning style survey for college. DVC Online. Available on the Web: http://www. metamath. com/lsweb/dvclearn. htm (refereed: February 24, 2005).

[16] Kharb, P., Samanta, P. P., Jindal, M., \& Singh, V. (2013). The learning styles and the preferred teaching-learning strategies of first year medical students. Journal of clinical and diagnostic research: JCDR, 7(6), 1089.

[17] Moussa, N. (2014). The importance of learning styles in education. Institute for Learning Styles Journal, 1(2), 19-27.

[18] Mustaffa, R. (2006). The effects of culture on students' learning styles. 3L: Language, Linguistics, Literature ${ }^{\circledR}, 12$.

[19] Oxford, R., Ehrman, M and Lavine, R. (1991). Style Wars: Teacher-Student Style Conflicts in the Language Classroom. In Magnan, S (ed)., Challenges in the 1990's for College Foreign Language Programs (pp. 1-25). Boston: Heinle and Heinle.

[20] Peacock, M. 2001. Match or mismatch? Learning styles and Teaching styles in EFL. International Journal of Applied Linguistics, 11(1), 1-20.

[21] Qasim, D. S. (2007). A study of computer literacy among foreign language learners at Sohor University in Oman. Unpuplished master thesis submitted to the school of linguistics and language studies, FSSK, National University of Malaysia.

[22] Reid, J. (1995). Learning styles in the ESL/EFL classroom. New York: Heinle and Heinle Publishers, pp. viii- xvii.

[23] Robinson, B. K., \& Dearmon, V. (2013). Evidence-based nursing education: Effective use of instructional design and simulated learning environments to enhance knowledge transfer in undergraduate nursing students. Journal of Professional Nursing, 29(4), $203-209$.

[24] Rogers, K. M. A. (2009). A preliminary investigation and analysis of student learning style preferences in further and higher education. Journal of Further and Higher Education, 33(1), 13-21. 
[25] Sarasin, L. C. (1998). Learning Style Perspectives: Impact in the Classroom (Madison, Wisc.

[26] Seidman, I. (2006). Interviewing as qualitative research: A guide for researchers in education and the social sciences. Teachers college press.

[27] Wong, S. Y., \& Zakaria, M. H. (2004). Learning Style Preferences Among Utm Students In Learning english: A Look Into Gender, Proficiency, Similarities And differences With Teaching Style [Doctoral dissertation, Universiti Teknologi Malaysia].

[28] Zhenhui, R. (2001). Matching teaching styles with learning styles in East Asian contexts. The Internet TESL Journal, 7(7), 5. 